\title{
AIS Research Database 1986 - 2004
}

Paul D. Hutchison, (Email: hutchp@cobaf.unt.edu), University of North Texas, Denton

The purpose of this research note is to advise accounting researchers about the availability of a downloadable database that contains accounting information systems (AIS) articles from 1986 to 2004. The author created this Microsoft Access database in order to disseminate knowledge about these AIS articles to fellow researchers. The database is fully searchable and contains 536 AIS articles and 243 other items from 1986 (or initial year of publication) through most recent publication in 2004 for the following three journals: International Journal of Accounting Information Systems (IJAIS) (formerly Advances in Accounting Information Systems)(AiAIS) (1992 - May 2004), Journal of Information Systems (JIS) (Fall 1986 - Spring 2004), and Review of Business Information Systems (RBIS) (formerly Review of Accounting Information Systems)(RAIS) (Winter 1997 - Summer 2004). ${ }^{1}$

The AIS Research Database re contains one record per author for each article or item to facilitate ease in search by author (e.g., if there are three authors, then there are three records.) There are 1,348 total records in the database. Each record contains the following 17 distinct fields (if available): journal name; title of article or item; author's first and last names; the journal edition's volume, number, season, year, and page number(s); category within the journal if identified (i.e., Main, Academic, Discussion, Education, Practice, Editorial, Dissertation Summary, Book Review, etc.); designation of sole or multiple authorship; author's university at publication; author's university department and rank at publication; and university where the author received their highest degree, the degree, and year of award.

Two data sources were utilized in the creation of the database: 1) information obtained directly from the journals from 1986 to most recent publication in 2004, and 2) the Accounting Faculty Directory (1987-2004) compiled by J. R. Hasselback. In total, the database contains 103 IJAIS/AiAIS articles (243 records for all IJAIS/AiAIS articles and items); $190 \mathrm{JIS}$ articles (595 records for all JIS articles and items); and 243 RBIS/RAIS articles (510 records for all RBIS/RAIS articles and items).

The AIS Research Database can be downloaded for use from the following website: www.coba.unt.edu/ acct/faculty/hutchison/database/ais/ais.htm

\section{REFERENCES}

1. Hasselback, J. R., 1980-2004. Accounting Faculty Directory. Englewood Cliffs, NJ: Prentice Hall, Inc.

\footnotetext{
${ }^{1}$ Other items include: Editorials, Discussions, Reports, Book Reviews, Dissertation Summaries, etc.
} 
NOTES 